\title{
31 \\ Haiti and the Early American Imagination
}

\author{
Michael J. Drexler
}

In 1903, W.E.B. Du Bois described being black in America as the experience of continuously being confronted with an unasked question: "How does it feel to be a problem?" (2015: 3). He wrote this after what he had called the "splendid failure" of Reconstruction in 1877 (1935: 708), when Federal troops were removed from the South and the protections and promises of the Freedmen's Bureau were curtailed. Nascent Haiti appears to have been similarly reckoned a problem in early America, and it bears noting that absent any equivalently grand gesture to reconstruct it, Haiti has continued to appear in the American imagination as such, a failed state seemingly impervious to humanitarian or political reformation. We may now marvel that it took the United States over 60 years to officially recognize Haitian independence or that France, which cynically levied a $\$ 3$ billion indemnity against Haiti for the value of lost slaves and property in exchange for officially recognizing the republic in 1825 , released Haiti from this vengeful debt burden only after the traumatic earthquake of 2010 . Imagine: Haiti's debt payments to France equaled $80 \%$ of its government budget before the US invasion in 1915 (Dubois 2012: 7-8). Not inconsequentially, France still refuses to pay reparations, despite acknowledging slavery and the slave trade as crimes against humanity in 2001. Nevertheless, despite 300 years of brutalizing plantation slavery and being ostracized and extorted for two centuries after independence, Haiti can still be depicted as victim of its own making: American pundits, like the New York Times' David Brooks (2010), for example, still brazenly blame the Haitian people for their nation's ongoing struggles. We may conclude that outsiders have

A Companion to American Literature, First Edition. General Editor: Susan Belasco.

Volume Editors: Theresa Strouth Gaul, Linck Johnson, and Michael Soto.

(C) 2020 John Wiley \& Sons Ltd. Published 2020 by John Wiley \& Sons Ltd. 
rarely appreciated Haitian history even while making so-called humanitarian decisions ultimately detrimental to its future. But even before the drama of official US recognition in 1865 or the US Marines' long occupation of Haiti from 1915 to 1934, early American writers struggled to understand the global historical significance of the Haitian Revolution.

The following pages aim at three goals. I will review recent scholarship about Haiti and the early United States to situate the study of the Haitian Revolution in US literary studies. I next turn to Leonora Sansay's Secret History; or, The Horrors of St. Domingo (1808), the first American novel to focus on events in pre-independent Haiti. Despite Sansay's considerable attention to social life at Cape Français, I will argue that domestic politics, especially surrounding the trial of Aaron Burr for treason, best illuminate the imaginary function of Haiti for early Americans. Finally, I will briefly look at further resonances of the Haitian Revolution in American culture. I will demonstrate that confusion and misinformation about Haiti have had lasting effects that cannot be dismissed once factually corrected by historiography. Not only were early Americans looking through a distorted lens at current events in the Caribbean basin, but they were also, perhaps primarily, looking not abroad, but at themselves.

\section{Mistakes Are Meaningful}

Misprisions of ideology or of the unconscious are themselves fascinating objects of study. Work of this nature has been undertaken within the relatively new field of Atlantic studies, which formed out of frustration with the silences surrounding the slave trade typical of state-centric histories of the eighteenth and nineteenth centuries. These Atlanticists followed the lead of foundational postcolonial critics, many of whom had connections to the Caribbean, including C.L.R. James, Frantz Fanon, and Édouard Glissant. It would be hard to overstate the influence that first-wave Atlanticists like Paul Gilroy and Michel-Rolph Trouillot had on shaping the work of the last 20 years. Special recognition is due to Alfred D. Hunt, who published the first monograph dedicated to, as his title makes clear, Haiti's Influence on Antebellum America (1988). "For the most part," Hunt writes, "Americans are not aware of Haiti's historical significance and its influence on American life" (1). Hunt then breaks his analysis down into a brief survey of Caribbean and Haitian history and the attitudes of several parties: Federal officialdom, northern merchants, southerners both deep and mid-Atlantic, and African Americans. Hunt can be credited with setting an agenda for future studies about Haiti and the United States. He began with a charge that for many Americans still remains apt today. Colin (Joan) Dayan was among the first American literary critics to draw attention to the impact of the Atlantic world on the shape of culture in the United States, especially on its literature. Dayan's first book was about Edgar Allan Poe, a writer now frequently understood as being deeply enmeshed in the logic of racism. Haiti, History, and the Gods (1995) broke new ground, introducing Americanists to the itineracy of 
religious and cultural ritual from Africa and the Caribbean to North America. She introduced the field to the novels of Leonora Sansay, the first US writer to set her plot in Saint-Domingue.

If it is no longer true that Haiti's relation to the early United States is neglected, it is still the case that Haiti enters today's American consciousness only at times of crisis: the American occupation from 1914 to 1934, the massive influx of refugees from political oppression in the 1980s, and, we must now add, the immediate aftermath of the catastrophic earthquake of 2010 and Hurricane Matthew in 2016. Inspired by Hunt's initiative, scholars in the United States have published numerous essay collections and monographs dedicated to mapping and understanding the early republic in relation to networks of cultural and economic domination and exchange extending from the Caribbean to Canada, from Boston to Venezuela, and especially from SaintDomingue/Haiti to the United States. ${ }^{1}$ Evident in many recent works by US scholars is the tension between two foci of concern: repercussions of the Haitian Revolution in the United States versus the effects in the broader Atlantic world. Marlene Daut (2011) rightly observes that, for most of these studies, "the U.S. - its authors, its politics, its history and its traditions - remains at center stage in studies that purport to be about Haiti." Her caution that we may, in either pursuit, have forced "the Haitian people into a secondary position whereby they operate within the margins of their own cultural and political history" is salutary and sobering (375). Nevertheless, scholars can no longer ignore the history of Haiti and of Caribbean slavery in their examinations of the construction of American culture.

Though I will now turn my attention to a novel by a white woman set during the Haitian Revolution and published shortly after the declaration of Haitian independence, it is essential to note that published African American responses to the Haitian revolution do exist but post-date my focus, which centers on reactions to Haiti during the Revolution and the first decade of independence. Freedom's Journal, the first African American newspaper, published editorials on Haiti and the first African American short story, "Theresa - A Haytien Tale" (1827). Three of the most important African American authored publications prominently featuring Haiti come later in the nineteenth century: James McCune Smith's A Lecture on the Haytien Revolutions (1841), Theodore Holly's Vindication of the Capacity of the Negro Race for Self Governance and Civilized Progress (1857), and William Wells Brown's St. Domingo: Its Revolution and Its Patriots (1855) and The Black Man, His Antecedents, His Genius, and His Achievements (1863). Turning to Sansay should not be taken to occlude the importance of African American commentaries on Haiti. Rather, I hope it will encourage methods of literary analysis that make legible these underrepresented and difficult to recover voices. To do this, we need to read through the distorted lens of white observers and to inhabit the curiosity and fantasy therein. This may be the distinctive contribution of literary historians: not to clear away the fallacies to get to a truer picture, but to heighten our attention to how such distortions and oversights drive meaning making and create the horizons of what can be written and consumed. 


\section{An Aspiring Novelist Rises}

Whether symptomatic or diagnostic, Leonora Sansay's 1808 novel Secret History; or, The Horrors of St. Domingo (2007), represents an early expression of the distortion and neglect that so often obscures Haitian history. Roughly tracking the author's own experiences in Saint-Domingue circa 1802, Secret History is an epistolary novel consisting of 32 letters. The first 26 letters are directed from Mary, a witty, perceptive, and unattached woman, to Aaron Burr, then the sitting Vice President of the United States. Mary is in Saint-Domingue along with her sister, Clara, beautiful and flirtatious but wretched because she is married to St. Louis, a vain, ragingly jealous, and insipid French officer who had fled from Saint-Domingue to the United States when his property was lost to the slave rebels. A reinvasion of the island under the command of Napoleon's brother-in-law, Charles Leclerc, inspires St. Louis to return to claim his plantation, but this goal will not be achieved. When the invading forces are ultimately thwarted, St. Louis flees to Cuba and finally debarks for France, but, as the last six letters tell, without Clara. In Cuba, St. Louis's jealousy boils into physical abuse, and Clara decides to leave him, making her own flight through the Cuban interior to Jamaica, where she will reunite with her sister. Letters 26-31 comprise correspondence between the two sisters. Mary is concerned about what she takes to be Clara's rash decision to abandon St. Louis, while Clara justifies her decision and writes of her experiences in the Cuban interior. In the final letter, Mary resumes writing to Burr to inform him that she and Clara are returning to Philadelphia, where she hopes that he might serve as Clara's "friend and protector" (154). Though Mary does refer to receiving letters from the Vice President, none of these are reproduced in the novel.

As this brief summary makes clear, Mary takes little interest in the justice or progress of the black rebellion, noting only once that the former slaves "broke the yoke" of their oppressors and "claimed the rights of which they had been so cruelly deprived" (77). On other occasions, she fantasizes about being "fanned to sleep by silent slaves" were St. Louis's plantation to be regained (72), and she saves most of her empathy for the creole inhabitants, depicted as victims of both their former slaves and the French officer class sent to restore order. If the reader is led to value Mary's perspective in the first two-thirds of the text, one may experience the last third differently. Mary, it seems, reveals herself a conservative hand-wringer, while Clara discovers new sources of fulfillment and a less self-absorbed view of her circumstances once liberated from the tyranny of her husband. Her newfound openness leads her to contemplate a more generous assessment of the non-white peoples she encounters. Clara's letters rebuking Mary for insisting that she conform to authority and return contrite may, then, encourage readers to rethink the authority granted to Mary on the basis of her perspectival control of the novel up until this point. Might Mary's dominant concerns - to disparage the French ruling class, to uphold the resolve of the white creoles, and to ennoble American virtues - also invite criticism?

The end of the novel, at least, leads us to consider the possibility that Sansay crafted Mary's views to be always only partial, both incomplete and biased. That is, if Mary is a 
vehicle for her presumed audience to see Haiti, giving them the eyewitness account upon which to understand the horrors of St. Domingo, we may conclude that Sansay's decision to undermine her credibility could call readers' interpretive confidence into question as well. Much of the intrigue in reading Secret History emerges from this uncertainty about how to assess what we are being invited to evaluate. Why do we trust a narrator more interested in the next dance party than in the violent suppression of dissent within the French ranks or the justness of their campaign to re-enslave the black population? What attracts us to a narrator who finds mixed-race prostitutes alluring, but also celebrates the virtues of American monogamy? The answers may lie as much in the frame as in the content of the novel. For, as the title page explains, this is not only an historical novel but one that historicizes itself as well. Sansay's references to Burr and Rochambeau point not only to the historical moment that is represented (1802), but also to the historical moment of its construction (1808). Though separated by only six years, we must not underestimate how quickly circumstances can change. One need only look at the way Sansay's novel was advertised to see how heavily this second context inflects the whole:

A NEW INTERESTING WORK.

JUST published and for sale at the Book-

Store of Matthias Ward, No. 149

Pearl-Street

SECRET HISTORY,

OR,

THE HORRORS OF ST. DOMINGO

In a series of letters written by a Lady at

Cape Francois to COLONEL BURR.

PRICE ONE DOLLAR

$* * *$

JUST received from Washington and for

sale by MATTHIAS WARD, No. 149 Pearl-

Street, price $\$ 150$ cents Vol 1, of the Trial of

COLONEL AARON BURR,

On an Indictment for Treason, before the Circuit

Court of the United States, held in Richmond

Virginia, May Term, 1807

$* * *$

HORRORS OF ST. DOMINGO

This day published by Samuel P. Brad-

Ford, in a 12 mo volume, price one dollar, for sale by

Alsop, Brannau, \& Alsop,

No 1, City Hotel, Broadway.

Secret History, Or, The Horrors Of St. Domingo

In a series of letters written by a Lady at

Cape Francois to COLONEL BURR. ${ }^{2}$ 
I claim that attending to the bitemporal field highlighted in the advertisement not only animates a richer interpretation of the novel for critics reading it today, but also indicates how Americans at the time received and responded to events in Haiti both introspectively and parochially. If the Haitian Revolution shocked the American imagination, it did so by transposing its narrative into a local, nationalist key.

The opening chapter of the novel gestures both toward the content to come and its encapsulating frame. Sansay chooses a most poignant occasion for the arrival of her protagonists at Cap Français. ${ }^{3}$ The timeline is crucial. It is 9 June 1802 . We know this because Mary writes of a momentous event nearly simultaneous to her party's landing. After a journey lasting 40 days, Mary, Clara, and St. Louis reach the northern port city on the same day that Toussaint Louverture, the former black revolutionary leader and once General-in-Chief of Saint-Domingue, had been arrested and was soon to be placed on a ship to France, where he would die in prison a year later. Why such precision with the date? I claim that Sansay understood this narrowly missed convergence as an example of the parallactic shuttling, the transposition of one perspective into another, so indicative of the novel's structure. With one glance, the novel both looks and does not look. It is setting as preterition; it sees through the rhetorical equivalent of pointing out what is being overlooked. Louverture is mentioned, but only briefly and only to be dismissed, his legacy buried, just as, reputedly, was his gold. Toussaint, the rumor goes, shot the men who were tasked with hiding his wealth in the woods before his arrest, Mary writes, leaving no one to report its location (63). It is tantalizing to consider Toussaint himself, like his gold, as the secret history that yet remains unrevealed. After all, upon his capture, Toussaint was alleged to declare, "In overthrowing me, you have done no more than cut down the trunk of the tree of the black liberty in St-Domingue; it will spring back from the roots, for they are numerous and deep."

We get only occasional further mention of Toussaint from Mary, and these instances, perhaps surprisingly, offer some commendation of the erstwhile general. The white creoles report that they felt themselves better treated under Toussaint than either Leclerc or Rochambeau, under whose rule the creoles were consistently treated without respect by the newcomers. As with the creoles' property, protected from wanton pillaging under Toussaint, sexual relations had also been more regulated before the French invasion. Toussaint had defended both religion and marriage. Mary tells us about a white gentleman who had cast aside his mistress, formerly a maid in his household. Toussaint intercedes when he learns that the man had found a new mistress and forces him to marry Madame A---, the spurned woman, because she had been elevated and maintained as a spouse in all but name. But under the present regime of Donatien Rochambeau, she continues, circumstances have deteriorated. Mary points to a convent that has been disbanded, the former nuns marrying because of the "license of the times" (94). We may wish to know more, but Mary's interest in the past is fleeting. The "rage for abolition" (94) in Paris had ruined St. Domingo, as had the French Revolutionaries' purge of the Church. Mary implies that Toussaint had reestablished a semblance of order once the revolutionary moment had collapsed, but Napoleon's rise to power and his legatees' miscalculations had undone things once again. 
When Toussaint's trace resurfaces in the trope of the bad man capable of moral action, it does so in the figure of another all but absent figure, Aaron Burr, to whom Mary, despondent over her sister's misery, appeals in letter 5. Like Toussaint, who had stepped in to save Madame A--- from being abandoned by her lover, Burr occupies Toussaint's position, the now distant but remembered protector. Mary recalls the similar service that Burr had performed for herself: "An orphan without friends, without support. [...] Cast on the world without asylum, without resource, I met you: - you raised me - soothed me - whispered peace to my lacerated breast. Ah, can I ever forget that delightful moment when your care saved me?" (79).

Though direct reference to Burr is rare despite his role as addressee, these instances do invoke Sansay's title: Secret History; or, The Horrors of St. Domingo, in a Series of Letters written by a Lady at Cape Francois to Colonel Aaron Burr, Late Vice-President of the United States, Principally under the Command of Rochambeau. Looking backward from 1808, Sansay points to not one scandal-ridden, deposed savior, but actually to three, transposing the titularly unnamed Louverture into his American and French avatars. Napoleon had appointed Rochambeau to replace his brother-in-law, Charles Leclerc, who had been commissioned to restore slavery and stabilize Saint-Domingue. When Leclerc died from yellow fever soon after Louverture's arrest, Rochambeau was to continue his mission, but instead squandered the French advantage by concerning himself with looting the island's wealth for himself and his officers. Aaron Burr, one electoral vote shy of the presidency in 1801 , was by 1808 not only the murderer of his political and personal rival, Alexander Hamilton, but an indicted traitor, accused of plotting to colonize Mexico, proclaim himself Emperor, and march on Washington to kill then President Thomas Jefferson. Thus, Sansay sets up a politics of relation, of substitution and displacement, through which the American imagination ricocheted when considering the meaning of Haitian independence: Burr, St. Domingo, Napoleon, Louisiana, and the border with Mexico. The advertisement quoted above materializes this path of signification: two advertisements for Sansay's novel juxtaposing Colonel Burr and General Rochambeau sandwich the transcript of Burr's spectacular trial for supposedly fostering insurrection in the Louisiana Territory.

Given Leonora Sansay's personal relationship with Aaron Burr, one might regard the reference to him to be ancillary to the novel proper, a way to bait readers with the promise of learning not only about St. Domingo, but about the notorious domestic rebel. Like most Americans, however, Sansay and her publishers were not alone in refusing to see the slave rebellion and Haitian independence as in any way analogous to their own anti-colonial struggle against England. This failure of the imagination is what led a leading Haitian intellectual, Michel-Rolph Trouillot (1995), to describe the Haitian Revolution as "unthinkable" to Euro-American observers (73). With this idea, Trouillot had something quite particular in mind: the revolutionary motivations of the rebellion on Saint-Domingue. Though citizens of both France and the United States had just experienced revolution and nation building themselves, very few of these contemporaries were willing to find common cause with either the former slaves or the gens de couleur (mixed race) who held, then lost, and then regained their freedom 
and, in the end, the island nation's independence. Early news of the colony-wide slave revolt inspired various reactions, but almost no one suggested that the eruption of violence presaged a third great revolution against tyranny. On the rare occasion when events seemed anything less than terrifying to Americans north and south, observers would point to the benefits to be enjoyed due to a rival's misfortune. Absent identification with the 500000 slaves, who began burning plantations on 1 August 1790, or with the mulatto elite, who pled for representation in the French Constitutional Assembly, Anglo-Americans saw Haiti through a narrow prism. After all, what did it have to do with them? Wasn't this France's problem?

Such questions were compounded because nearly everything Americans could learn about Haiti had to be translated for them. Racism and self-interest, let alone the French language, obscured how the Haitian Revolution might fulfill the promise of their own revolutionary slogan, "give me liberty or give me death!" Into the breach stepped interested parties. Northern merchants wondered how it would affect the bottom line. Southern plantation owners worried that their slaves would turn violently against their masters. This was the fear southern politicians stoked as they decried the horrors of St. Domingo. Would refugees flood the mainland, bringing with them perverse ideas incompatible with the newly adopted Constitution? Was revolution a contagion comparable to the yellow fever that originated, they presumed, in the Caribbean and that turned American cities into ghost towns during the summer months? And hadn't these Frenchmen just murdered their king, abolished religion, and toyed with recklessly emancipating their slaves? Then, consider this newcomer, Napoleon, sending his armies abroad with imperial ambition. Would events in SaintDomingue limit or encourage this self-declared emperor from eyeing North America as his ultimate prize? There were many variables to consider along with potentially more pressing concerns. Was Britain still an enemy or now an ally fighting the spread of Jacobin terror? President Washington had cautioned against foreign entanglements, but President Adams sought stronger ties with Britain. His Alien \& Sedition Acts (1798) were aimed at Irish and French radicals to limit Jacobinism. James Alexander Dun (2016) contends that Americans "fabricated" a Haitian Revolution for themselves and their own particular interests. Developments in Haiti "were integral parts of the heat of domestic politics, which, by the late 1790s, had cauterized fissures and catalyzed new realities, hardening them with the passion and warmth of the times" (22).

Then the election of 1800 brought a new party to power. Though Thomas Jefferson, like Washington, hailed from the slaveholding South, he spurned alliances with northern Federalists - like Alexander Hamilton - bent on centralizing commerce and empowering the federal courts. Charged with Francophilia, the new president had other rumored predilections as well. "A Negro president," said some Federalist critics derisively, broadly condemning the new president's well-known affair with his slave, Sally Hemings. While Washington's successor, John Adams, had courted quasi-independent SaimtDomingue to maintain and even strengthen trade with what had been the world's most profitable sugar colony, Jefferson pulled back from Adams's tacit acceptance of Toussaint Louverture and, in 1806, placed an embargo on American trade with the 
new black republic. Then under the rule of Jean-Jacques Dessalines, Haiti had made itself inhospitable to whites; Dessalines massacred the remaining whites on the island in 1804 and had declared himself the avenger of America upon the occasion of Haitian independence. Jefferson, who had cautioned that neither blacks nor whites would rule securely until the annihilation of one by the other in his Notes on the State of Virginia (1782), saw his predictions coming to realization. He answered Haitian atrocities with a debilitating embargo of the island.

\section{Novel Politics}

For scholars of early national American literature, all of this is rich material, a necessary addition to the contexts within which America's first class of professional imaginative writers plied their trade. Primarily residing in the northern merchant capitals of Boston, New York, and Philadelphia, these early novelists, dramatists, and opinionmongers shared the more ambivalent attitudes of their northern compatriots toward the Caribbean. Sean Goudie (2006) has referred to these unstable beliefs and feelings as "paracolonial" (11-12). No longer colonized themselves, but continuing to trade and profit from colonialized territories, northeastern Americans had ties to the West Indies that complicated the notion of their own cultural and economic independence. For Goudie, the Caribbean could seem the antithesis of the American national project, but, as Stephen Shapiro (2009) argues, ties to the Caribbean zone only strengthened as the Haitian Revolution developed into a full-bore anti-colonial rebellion (143). The chaotic Napoleonic Wars gave American merchants a near monopoly on the re-export economy of "low-grade fish for cheap molasses," the final vector in the notorious triangle trade in slaves and the products of chattel labor (Sepinwall 2009: 319). This trade produced vast wealth for a merchant class that increasingly distinguished itself from the old power brokers, the High Federalists of Boston and the plantation elite in Charleston. In between, mid-Atlantic port cities grew rapidly and transformed American politics in turn, the newly enriched merchant class able to switch political allegiance to the party best positioned to stabilize the carrying trade. Alongside this vigorous if execrable commerce, another exploited group also gained traction and selfawareness: a quickly trainable and young class of scribblers, human copy machines, worked to record transactions and maintain other mercantile protocols. These young, professional, hired pens turned, in what leisure time was afforded them, "to what was at hand, the literary, as their resources for explicating their situation. [...] they invoked fictional forms as the medium for thinking through the conditions of their insecurity [the uncertainties of market fluctuation and social and political upheaval]" (Shapiro 2009: 143). Thus there was a profusion of literary clubs and journals throughout the 1790s. A few of these individuals wrote novels, adapting a continental style to the new conditions of the American scene.

The novel form, dominated early by first-person narration, lent itself to the exploration of problems about identity and the relationship between individuals and the 
larger social collectives that bound them. Among these young writers was Charles Brockden Brown, the first American author to draw on Saint-Domingue/Haiti in fiction. In both Ormond, or The Secret Witness (1799) and Arthur Mervyn, or Memoirs of the Year 1793 (1799-1800), Brown, progeny of a mercantile family, identifies St. Domingo as a catalyst for unregulated and unpredictable social change. These references to the French Caribbean appear only sporadically in Brown's works, but their importance should not be underestimated. In Arthur Mervyn, for instance, when two SaintDominguan sailors are discovered aboard a trading vessel headed for Philadelphia, American naval sailors claim the entirety of the cargo as contraband, an act that destroys a fraudulent commercial scheme crucial to setting the plot in motion. In Ormond, an inscrutable female revolutionary, Martinette, counts St. Domingo among the stops on her way from Europe to America. In 1803, Brown wrote a hoax pamphlet entitled "An Address to the United State Government on the Cession of Louisiana to the French," in which the author pretends to have discovered a secret Napoleonic plan to leave SaintDomingue to the black rebels and focus on reclaiming a foothold in North America. The pamphleteer then urges the Jefferson administration to annex the Louisiana Territory, an act already under negotiation and completed during the same year. The boundary between fiction and politics remained fuzzy. Brown, who adopted the moniker of moral observer rather than author, prefaced Arthur Mervyn by asking it to be considered equal to both "the physician and the political economist" (Brown 2008: 3).

Besides Sansay and Brown, the only other American novelist directly to reference SaintDomingue was Martha Meredith Read. In Monima, or, The Beggar Girl, published anonymously in 1802, Read presents readers with a protagonist who seeks refuge in Philadelphia after "the great invasion of the slaves." The slaves' "savage barbarity" consumed the lives of two of Monima's siblings and the yellow fever takes her mother, too (214). But in the end, the patriarch Fontanbleu recovers his property in the colony, intact after having weathered the slave rebellion. Read placed part of her second novel, the romance Margaretta (1807), in Saint-Domingue as well, but, as Richard Pressman (2012) argues in his introduction to the text, this Saint-Domingue lacks any connection to its historical situation. Instead, he writes, "Read imagines a world in which there simply are no contaminations, no slave revolts, no war, neither at sea nor on land. [...] [It is a world] in which Americans can say we are against slavery, and for a strong, democratic work ethic, but in which we can live a cultivated, polite life of leisure provided, however indirectly in the North, by slave labor" (31). While Brown placed himself in a privileged position to analyze his times, Read regarded Saint-Domingue as an escape from history.

The comparative indifference of Read's novel - along with the general avoidance of the topic in most fictional writing of the period - highlights what makes Sansay's so unusual. Secret History entertains complex thoughts about the final days of French rule in Saint-Domingue, even while, as we have seen, it also deflects those thoughts toward more introspective concerns. In pivoting between the St. Domingo of 1802 and the circumstances of Aaron Burr in 1808, Sansay hints at another narrative of the Haitian Revolution, one that even she could not fully articulate or that she found too provocative to make explicit. This is the story of the American Toussaint. 
To pursue the sleight of hand through which St. Domingo oscillates with the chaotic story of Aaron Burr, we must dwell on a very brief moment when Toussaint did attract the gaze of American observers. The rise of Louverture, first as Governor General of Saint-Domingue in 1797, and then to Governor for Life with the promulgation of his Constitution in 1801, dramatically, if only temporarily, changed how the US population assessed the slave and anti-colonial rebellion on the island. Before Toussaint's assumption of power, Americans generally had difficulty separating the chaos in the French Caribbean from the French Revolution on the continent. As royalist refugees from France and colonial Saint-Domingue, each with their own tales of a world turned upside down, arrived in Philadelphia, Charleston, and Baltimore, Americans had reason to temper their enthusiasm for a sister republic in Paris. If Americans were concerned about chaos on the streets of Paris, this was amplified by its spread to the French possessions in the West. In Saint-Domingue, Americans could sense that the French Revolution could become their problem, too. The visit of Ambassador Genet to Philadelphia in 1794 also fueled the suspicion that dark, antireligious forces were conspiring to subvert American sovereignty. This line of thinking also reemerged after Louverture was ousted from power, when fear of a French invasion of Louisiana predicted Napoleonic conquest of the new United States. But the heightened interest in Louverture from his rise to power in 1798 until the promulgation of his constitution in 1801 is odd, because - whether from a Federalist or DemocraticRepublican perspective - the idea of Louverture is already curiously dissociated from the rebel masses and the portent of slave unrest for an American economy secured by slave labor. This dissociation may partially be explained because among Louverture's policies were rules to force the former slaves back onto plantations to resume sugar production, moves that some interpret as all but reinstating slavery. But equally, if not more important, is that Louverture appeared, paradoxically, to oppose the French Revolution's most radical goals. For instance, Louverture wished to establish Catholicism as the state religion.

As Gordon Brown has explained in his book Toussaint's Clause: The Founding Fathers and the Haitian Revolution (2005), merchants and their Federalist allies actually courted Louverture, counting on him to continue trade with the United States even amid the French embargo against it. The 1798 Toussaint Clause, while stopping short of recognizing Haitian independence, offered Louverture the stature of a leader of state. The promulgation of Toussaint's Constitution in 1801, a document that moved an unnerved Napoleon to depose his loyal servant, made Louverture even more valuable to American merchants. For his own part, Louverture continued to pledge allegiance to France. Though articulating a semblance of independence, the constitution did declare all citizens of the colony not only free, but French. Even before the announcement, translation, and circulation of Toussaint's Constitution, American newspapers throughout the States featured a biographical article entitled "The Character of the Celebrated Black General, Toussaint Louverture." It appears first in American Intelligencer and Daily Advertiser on 11 June 1801. The writer calls Louverture an "extraordinary man [...] born a slave," who having "gained sovereign sway over his fellow negroes" had 
risen to General-in-Chief and worked exclusively "in the name of the French Republic" and with the "strictest fidelity and honor." A subsequent anecdote in the article demonstrates Louverture's capacity for "gratitude and humility," and closes with the following declaration of his pragmatism:

It would be the disposition of a little mind, in Toussaint's situation, to hate and persecute the whites; but he knows well that the island cannot flourish without them; that they are necessary to cultivation and good government, to the commerce and prosperity of the place. Therefore his chief aim is to restore the planters, and revive the trade [...] he is anxious to find a market for the produce of the island. ("Character" 1801: n.p.)

By contrast, Democratic-Republicans, also indifferent to his role in the slave revolt, depicted Toussaint as an arch-Federalist bent on centralizing power and ruling as a tyrant. William Duane (1801) responded to the Federalist embrace of Louverture in the Aurora two months later on 17 August and just after the publication of the Constitution. "We are among those who deny the competency and question the legality of the authorities assumed by the extravagant organization which has lately been set up in St. Domingo," he wrote. "In the new system of what is called a constitution, we see nothing to respect, nothing to admire, and much to excite abhorrence and disgust." The constitution was "a spurious mimicry" of its French antecedent, "a new made monster, $[\ldots]$ a despotism of the worst kind, formed in the worst manner, conceived in treachery and masked by hypocrisy" (n.p.). Toussaint's Constitution, we can see, became another referendum on Federalism, an off-center attack on the pretension of John Adams and Alexander Hamilton and a spirited defense of the civility and righteousness of the toppled ruling class.

As Drexler and White (2014) have argued, the split over the meaning of Louverture's rise and fall was transposed from the Caribbean into the Mississippi Valley and onto the figure of Aaron Burr (102-167). The catalyzing element was Louisiana, a vast territory that had been swapped between Spain and France and whose pivotal center was New Orleans. The miscellany of people and cultures that continue to make New Orleans remarkable today included Spanish colonial administrators, French refugees from both the continent and Saint- Domingue, African and Indigenous slaves, Cajuns, and American adventurers, or filibusters. In New Orleans and greater Louisiana, the inter-imperial conflicts of the mid-century Seven Years' War - arguably the first world war - continued to seethe. At issue was control of the Mississippi Valley and access to the Gulf, that, along with the Floridas, were the closest trading posts to the Caribbean plantation system. When rumors of Spain's cession of New Orleans to the French turned out to be true, Thomas Jefferson faced pressure to invade and prevent Napoleon from establishing a new front in North America. In the end, Jefferson was able to make the greatest real estate deal in history, purchasing the entire territory from France in 1803.

Jefferson's purchase of the Louisiana Territory put the French threat temporarily to rest, but raised many questions left unresolved during the first decade of the US Federal Republic. Would slavery spread to the west? Would the United States reach the limits of its capacity to secure its borders? Would Indians and slaves unite, in one 
Congressman's remarks, to raise the "tomahawk of the savage and the knife of the negro" and joining with France bring upon the States "no interval of peace?" (Debates 1804: 78-79). Aaron Burr emerged at the epicenter of these concerns. In the winter of 1803 , and into the following spring, a contingent of northern Federalists courted Burr to lead a northern secession from the union. They were prepared to jettison the South and leave slavery as someone else's problem. But in June, the infamous duel ending with the death of former Secretary of the Treasury Alexander Hamilton occurred, disrupting the scheme. Jefferson dropped Burr for his second campaign, and, dishonored, having failed in a bid to become governor of New York, the former vice president headed west, striking into the very heart of the nation's most pressing anxieties. I refer, of course, to the notorious Burr Conspiracy for which he was indicted and tried for treason. In The Traumatic Colonel: The Founding Fathers, Slavery, and the Phantasmatic Aaron Burr (2014), Drexler and White trace how Burr emerged at the turn of the century as Jefferson's foil, a racialized and sinister figure, a secret agent of Federalism, but also a murderer, a fugitive, and a traitor. After the infamous duel with Hamilton, Burr continued to serve as President pro tempore of the Senate, his main responsibility as Jefferson's vice president. In this role, he oversaw the impeachment trial of Supreme Court Justice Samuel Chase. Lauded for his equanimity during the trial, Burr then resigned his post with greater ambitions. He made two trips west, which the newspapers followed minutely and set a rumor mill whirling. Jefferson also followed reports of Burr's doings and, when convinced that Burr might indeed be planning an insurrection, he had Burr arrested. The conspiracy had ended before it had even begun. Burr stood indicted for treason and went to trial, where he ultimately was found "not proved to be guilty" (Robertson 1808, vol. 2: 446). Though historians haven't settled whether the conspiracy was real or how far along it had proceeded, at the trial in Richmond (1807-1808) one deponent left little to the imagination, averring under oath that Burr had been determined to "turn Congress neck and heels out of doors; assassinate the President; seize on the treasury and the navy, and declare himself the protector of an energetic government" (Beveridge 1916: 304). This is Burr as the American Toussaint, the turncoat of the republic (as Napoleon had viewed Louverture) and avenger of the government's inability to secure the Louisiana Territory, marshaling a non-white army to overthrow it. Only the semiotic residue of this claim may be found in the traditional historical record, which brings us back to Leonora Sansay's provocative novel, to the buried story of Toussaint Louverture in its pages, and to the silent addressee of its epistles.

Though in no position to offer refuge or relief at the time that Sansay's novel came off the presses, Burr does appear to have remained in contact with Sansay from her return to Saint-Domingue up until the trial of 1808. Here, the novel-space dovetails with the life of the author, who seems to have imagined herself split into the personae of the two sisters for the purposes of fiction. She hints at as much in a letter dated May 6, 1803 from Cape François, which contains the plot of the first half of Secret History, suggesting that she and Clara were one and the same. In it, Sansay teases Burr with the adventures of Clara, "that Clara you once lov'd. She came to St about the time I did" 
(225). Sansay surfaces again in 1808. Her name, or rather one of her aliases, appears in the Richmond Enquirer on 1 March, during the very trial that she and her publisher would exploit to sell her work. In his private correspondence, the architect Benjamin Latrobe confirms that Sansay, under the alias Madame D'auvergne, had delivered Burr's letters to him while he was in New Orleans. The alias, Madame D'avergne or D'auvergne, deserves some comment since there is no doubt that it referred to Sansay. Burr's compatriot and first biographer, Matthew Davis (1970), makes this clear in a footnote to his compilation of Burr's private correspondence (149). D'auvergne looks to be a francization of Sansay's maiden name Davern, from her mother's first marriage. ${ }^{4}$ In her last correspondence with Burr in 1817, after which we know little about her life, Sansay describes a flower manufactory she had started with the help of another Burr associate, Erich Bollman. Two or possibly three novels appeared from a British press, the first of which, Zelica, the Creole (1820) contains significant portions of Secret History, though with significant changes as well. Gone is the epistolary frame and reference to Burr, and in its place is a complicated romance between a French officer and Zelica, a mixed-race character whose white, radicalized father wishes to marry her off to one of Haiti's black generals. The Scarlett Handkerchief was published two years later. The Stranger in Mexico remains unfound. We now know that Sansay was buried in Newent, in the county of Gloucester, England in 1821 and this information may or may not resolve whether Sansay wrote the later novels, an issue which remains a matter of scholarly debate. Nonetheless, Leonora Sansay's place in the American literary canon now seems assured. It continues to inspire Americanists to investigate the many perambulations of the Haitian Revolution as it traveled to the United States.

Without question, the Haitian Revolution reverberated throughout the Caribbean during the nineteenth century and continued to influence both the slaves who found it inspiring and the slaveholders who feared its repetition. It dramatically influenced how Americans thought about westward expansion and the role of the United States in relation to peoples of color and the many territories in the western hemisphere that remained governed by European colonizers. As the United States expanded its sphere of influence and imagined itself as an empire with aims of abridging European power in the hemisphere, the aberration of Haitian resistance moved from the forefront of American consciousness to reappear in gothic eruptions disturbing the simpler story of irrepressible national progress. The horrors of St. Domingo resurface most acutely in moments of overt slave resistance such as Nat Turner's Rebellion and, later, John Brown's raid on the Federal armory at Harpers Ferry. But Haiti remains a presence for the authors of the so-called American Renaissance in sometimes cryptic allusions in the short stories of Edgar Allan Poe or, more pointedly, in Herman Melville's Benito Cereno. And, of course, the culture of Louisiana, and New Orleans in particular, was and remains inflected by the migration of French refugees from Saint-Domingue as well as by the hybrid religious rituals of voodoo that persisted despite the carceral totalitarianism of slavery. The lasting impact of these refugees on American culture is traced by scholars Dayan (1995) and Ashli White in Encountering Revolution: Haiti and the Making of the Early Republic (2012; see Further Reading), among others. The Civil 
War and the belated recognition of Haitian independence, it goes without saying, did not draw to an end the influence of Haiti on the culture of the United States, nor did the end of the 19-year occupation of the Haitian state by US marines in 1934. It lived on in Eugene O'Neill's play The Emperor Jones, William Faulkner's Thomas Sutpen of Absalom, Absalom! and endures still into our own moment in the ubiquitous zombie motif and innovative and challenging novels of Haitian-born immigrant Edwidge Danticat, among others. The Congressional Research Service estimated that there were approximately 757000 people of Haitian ancestry in the United States in a white paper dated 17 May 2011 (Wasem 2011), and the Associated Press reports that there are 41000 Haitian migrants in US detention center jails as of 18 November 2016 (Smith 2016). The history of these migrants and their descendants, if written, would demonstrate how economic, political, and cultural forces continue to yoke Haiti and the United States.

\section{Notes}

1 Saint-Domingue was the name of the French colony that would become Haiti in 1805 . I use Haiti generally in the context of the revolution, but Saint-Domingue when discussing the colony prior to 1791 , when the massive slave rebellion began.

2 The typography here reproduces the appearance of the advertisement, which appeared in several newspapers including American Citizen of New York on 20 February 1808.
3 Cap Français is the most common variant, though one finds the anglicized Cape and either Français or, as in Sansay's book, Cape François used as well.

4 Rosa Hassall had two additional children with Hassell, a daughter, Mary, and son, William. Jennifer Van Bergen (2010) has done the most to discover and verify these details.

\section{REFERENCES}

Beveridge, A.J. (1916). The Life of John Marshall, Vol. 3. Boston, MA: Houghton Mifflin.

Brooks, D. (2010). "The Underlying Tragedy." New York Times, 14 January.

Brown, C.B. (2008). Arthur Mervyn; or Memoirs of the Year 1793, ed. P. Barnard and S. Shapiro. Indianapolis: Hackett.

Brown, G.S. (2005). Toussaint's Clause: The Founding Fathers and the Haitian Revolution. Jackson: University Press of Mississippi.

"Character of the Celebrated Black General, Toussaint Louverture" (1801). American Intelligencer and Daily Advertiser, 11 June.

Daut, M. (2011). "Daring to be Free/Dying to be Free: Toward a Dialogic Haitian-U.S. Studies." American Quarterly, 63(2): 375-389.
Davis, M. (1970). Private Journal of Aaron Burr. New York: Literature House.

Dayan, C. (1995). Haiti, History, and the Gods. Berkeley: University of California Press.

Debates in the House of Representatives, on the Bill for Carrying into Effect the Louisiana Treaty (1804). Philadelphia: J. Conrad \& Company.

Drexler, M. and White, E. (2014). The Traumatic Colonel: The Founding Fathers, Slavery, and the Phantasmatic Aaron Burr. New York: New York University Press.

Duane, W. (1801). Editorial. Aurora, 17 August.

Du Bois, W.E.B. (1935). Black Reconstruction: An Essay toward a History of the Part which Black Folk Played in the Attempt to Reconstruct American Democracy. New York: Harcourt, Brace, and Company. 
Du Bois, W.E.B. (2015). The Souls of Black Folk. New Haven, CT: Yale University Press.

Dubois, L. (2012). Haiti: The Aftershocks of History. New York: Metropolitan Books.

Dun, J.A. (2016). Dangerous Neighbors: Making the Haitian Revolution in Early America. Philadelphia: University of Pennsylvania Press.

Goudie, S. (2006). Creole America: The West Indies and the Formation of Literature and Culture in the New Republic. Philadelphia: University of Pennsylvania Press.

Hunt, A. (1988). Haiti's Influence on Antebellum America: Slumbering Volcano in the Caribbean. Baton Rouge: Louisiana State University Press.

Pressman, R. (2012). Introduction. In M.M. Read, Margaretta. San Antonio, TX: Early American Reprints, pp. 13-44.

Read, M.M. (1802). Monima, or, The Beggar Girl. New York: Printed for P. R. Johnson.

Robertson, D. (1808). Reports of the Trials of Colonel Aaron Burr. 2 vols. Philadelphia: Hopkins and Earle.

Sansay, L. (2007). Secret History; or, The Horrors of St. Domingo and Laura, ed. M. Drexler. Peterborough, ON: Broadview Press.
Sepinwall, A.G. (2009). "The Specter of SaintDomingue: American and French Reactions to the Haitian Revolution." In The World of the Haitian Revolution, ed. D.P. Geggus and N. Fiering. Bloomington: Indiana University Press, pp. 317-338.

Shapiro, S. (2009). Culture and Commerce of the Early American Novel: Reading the Atlantic WorldSystem. State College, PA: Penn State University Press.

Smith, J. (2016). "Haitian Migrants Are Released from Crowded Jails in the US as Space Inside Detention Centers Runs Out." Associated Press International, 18 November.

Trouillot, M. (1995). Silencing the Past: Power and the Production of History. Boston, MA: Beacon Press.

Van Bergen, J. (2010). "Reconstructing Leonora Sansay." Another World Is Possible. http:// www.a-w-i-p.com/index.php/2010/01/03/ reconstructing-leonora-sansay (accessed 21 May 2019).

Wasem, R. (2011). U.S. Immigration Policy on Haitian Migrants. Washington, DC: Congressional Research Service, 17 May.

\section{FURTHER READING}

Allewaert, M. (2013). Ariel's Ecology: Plantations, Personhood, and Colonialism in the American Tropics. Minneapolis: University of Minnesota Press. Studies intersections between economy, ecology, and politics in the Caribbean during the years of the Haitian Revolution.

Clavin, M. (2011). Toussaint Louverture and the American Civil War: The Promise and the Peril of the Second Haitian Revolution. Philadelphia: University of Pennsylvania Press. Brings the influences of the Haitian Revolution on antebellum America up to the end of the Civil War, building on the work of Alfred Hunt.

Dillon, E. and Drexler, M. (2016). The Haitian Revolution and the Early US: Histories Textualities Geographies. Philadelphia: University of Pennsylvania Press. Collects essays by literary critics and historians.

Dubois, L. (2005). Avengers of the New World: The Story of the Haitian Revolution. Cambridge, MA:
The Belknap Press. Presents, along with Haiti: The Aftershocks of History, Dubois's concise but authoritative histories of the Haitian Revolution and the Haitian Republic.

Geggus, D. and Fiering, N. (2009). The World of the Haitian Revolution. Bloomington: Indiana University Press. Takes an internationally comparativist view of the revolution, the first collection of essays to do so.

Iannini, C. (2012). Fatal Revolutions: Natural History, West Indian Slavery, and the Routes of American Literature. Chapel Hill: Omohundro Institute and University of North Carolina Press. Examines how literature and works of natural history intersect in early American publications.

Jackson, M. and Baker, J. (eds.) (2009). African Americans and the Haitian Revolution: Selected Essay and Historical Documents. New York and London: Routledge. Presents essays and an anthology of primary documents. 
The Louverture Project: https://thelouvertureproject.org/. A host of resources relevant to study of the early United States and Haiti. Contains translations of important documents including the Declaration of Haitian Independence, letters, official pronouncements, and all of Haiti's constitutions.
White, A. (2012). Encountering Revolution: Haiti and the Making of the Early Republic. Baltimore, MD: Johns Hopkins University Press. Studies the impact of refugees from the Haitian Revolution.

See also: chapter 20 (the first black atlantic); chapter 23 (revolutionary print culture, 1763-1776); chapter 27 (charles brockden brown and the novel in the 1790s); chapter 29 (remapping the canonical interregnum). 